\title{
Hanford Environmental Dose Reconstruction Project
}

\section{Monthly Report}

July 1989
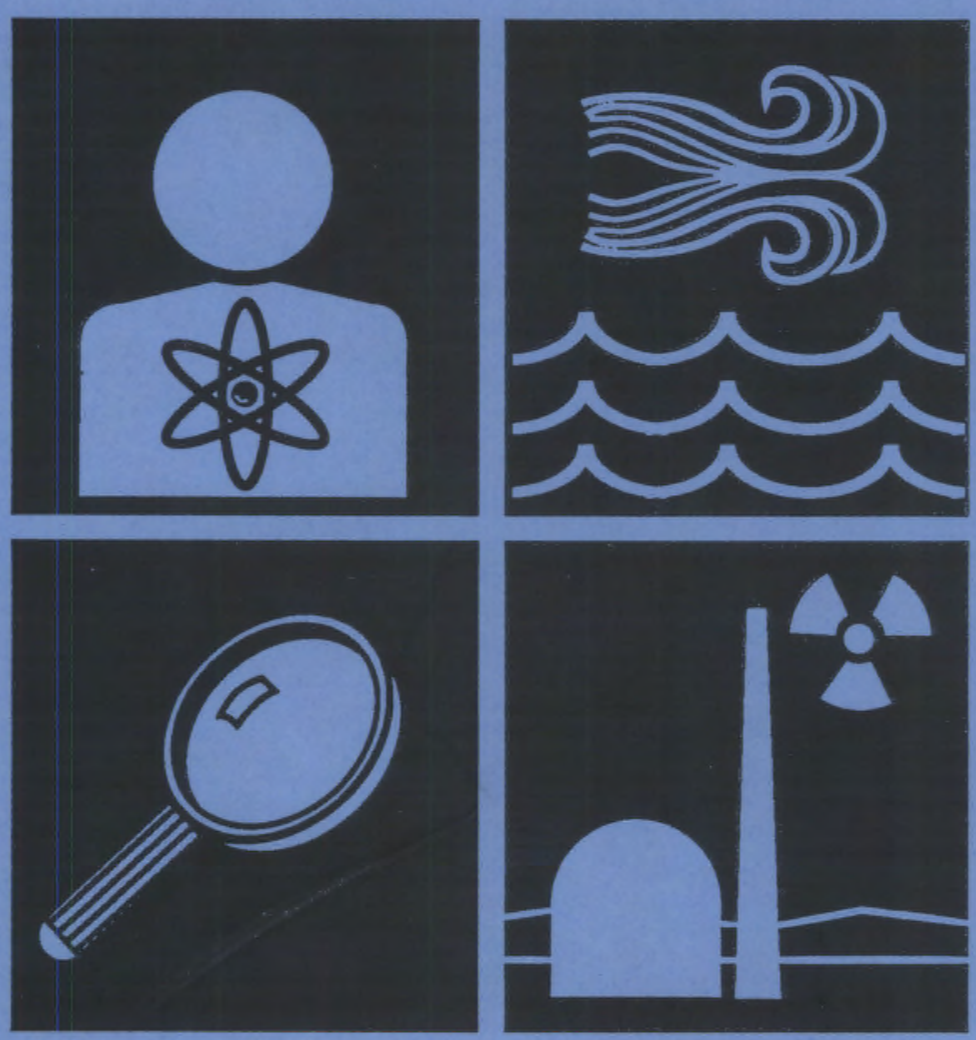

Prepared for the Technical Steering Panel 


\section{DISCLAIMER}

This report was prepared under the direction of the HANFORD ENVIRONMENTAL DOSE RECONSTRUCTION PROJECT Technical Steering Panel by Battelle Memorial Institute's Pacific Northwest Laboratories operating the Pacific Northwest Laboratory for the U.S. Department of Energy (DOE). While funding for the work was provided by DOE, the work is not under DOE direction or control. The views and opinions of the authors expressed in this document do not necessarily reflect those of the United States Government or any agency thereof. Reference herein to any specific commercial product, process or service by trade name, tradernark, manufacturer or otherwise does not necessarily constitute or imply its endorsement, recommendation or favoring by the U.S. Government or any agency thereof, nor by Battelle Memorial Institute. 


\section{HANFORD ENVIRONMENTAL DOSE RECONSTRUCTION PROJECT}

Monthly Report

July 1989

Prepared for the Technical Steering Panel

Pacific Northwest Laboratory

Richland, Washington 99352 
PNL-6450-21 HEDR

UC-707

\section{HANFORD ENVIRONMENTAL DOSE RECONSTRUCTION PROJECT}

Compiled by: B. alemas:

B. S. Dennis, Project Coordinator

Hanford Environmental Dose Reconstruction Project

Approved By:

H. A. Haerer, Project Manager

Hanford Environmental Dose Reconstruction Project

Approved By; 


\section{PREFACE}

This monthly report summarizes the technical progress and project status for the Hanford Environmental Dose Reconstruction (HEDR) Project (structure shown in Figure 1) being conducted at Pacific Northwest Laboratory (PNL) under the direction of a Technical Steering Panel (TSP). The TSP is composed of experts in numerous technical fields related to this project and represents the interests of the public. The U.S. Department of Energy (DOE) funds the project. 


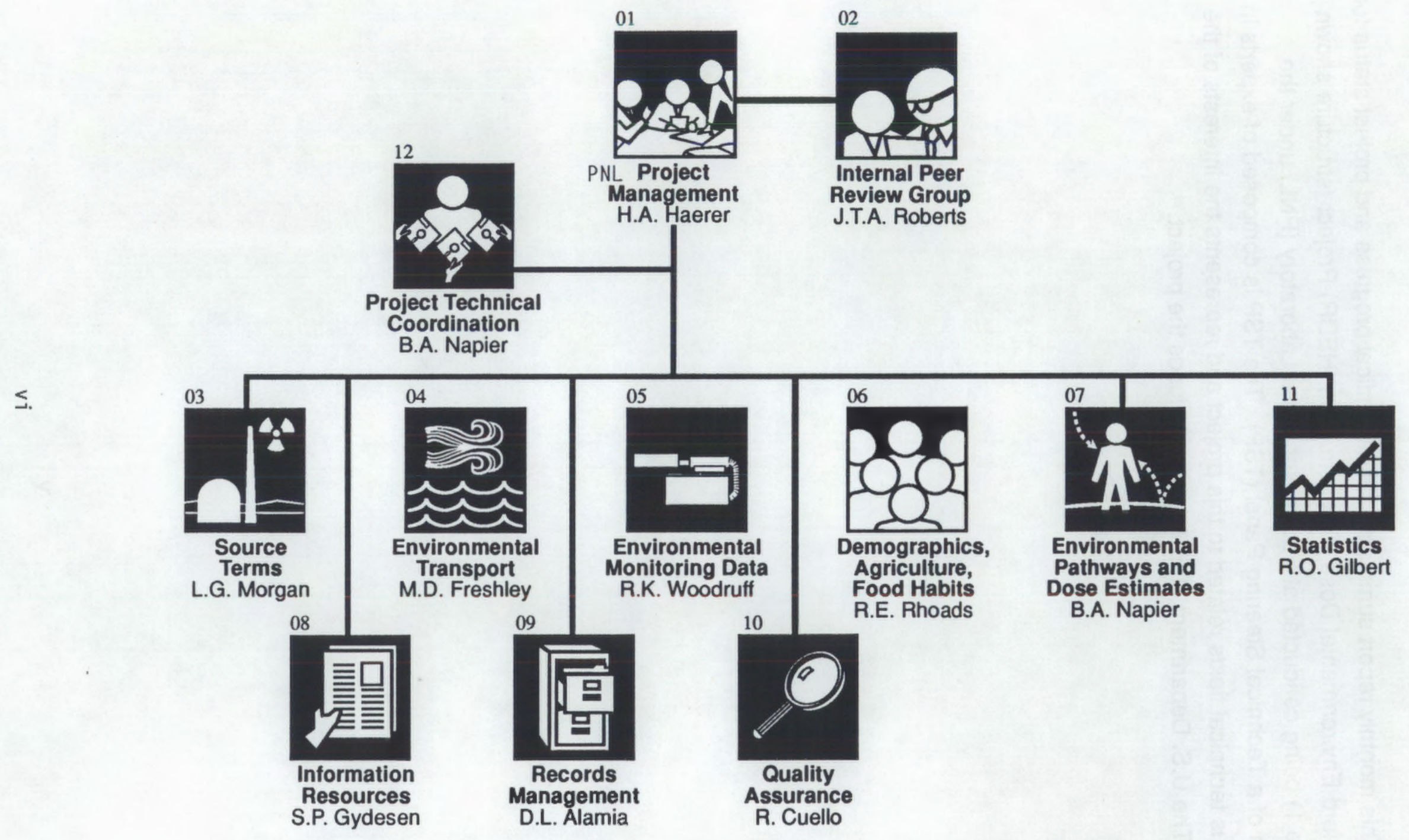

Figure 1. Hanford Environmental Dose Reconstruction Project Organization Structure 


\section{EXECUTIVE SUMMARY*}

The objective of the Hanford Environmental Dose Reconstruction Project is to estimate the radiation doses that populations could have received from nuclear operations at Hanford since 1944. The project is being managed and conducted by Pacific Northwest Laboratory under the direction of an independent Technical Steering Panel.

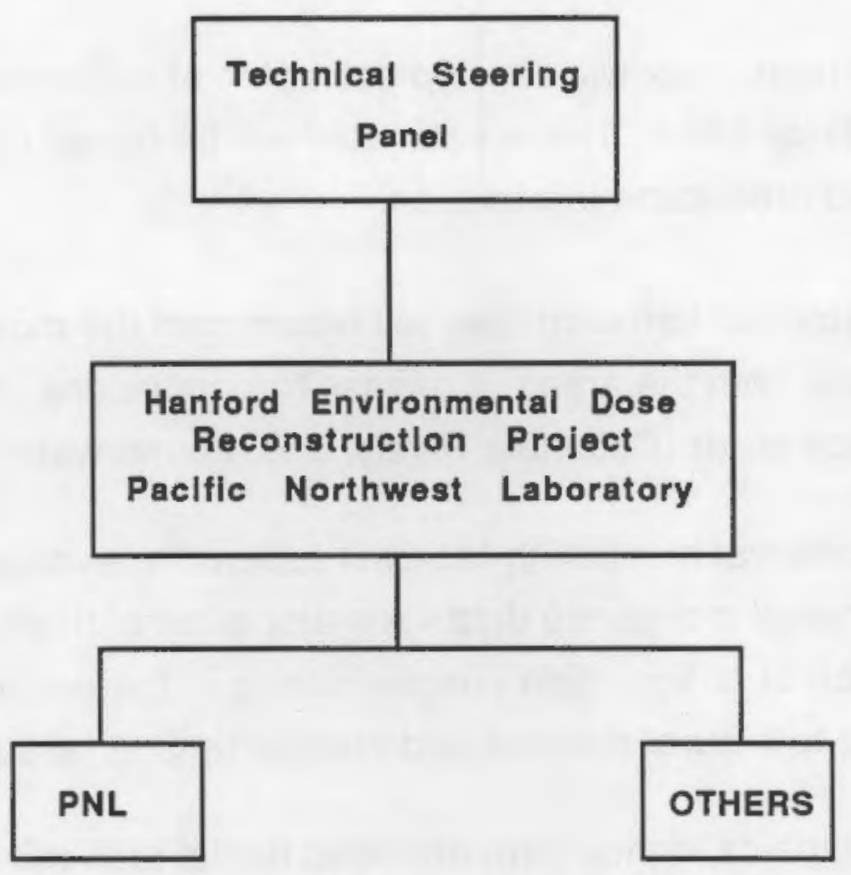

The Technical Steering Panel consists of experts in environmental pathways, epidemiology, surface-water transport, ground-water transport, statistics, demography, agriculture, meteorology, nuclear engineering, radiation dosimetry, and cultural anthropology. Included among the members are appointed technical members representing the States of Oregon and Washington, cultural and technical experts nominated by the Indian tribes in the region, and an individual representing the public.

This Executive Summary was approved by the Technical Steering Panel in September 1988. 
The project is divided into the following technical tasks. These tasks address each of the primary steps in the path from radioactive releases to dose estimates:

- source terms

- environmental transport

- environmental monitoring data

- demographics, agriculture, and food habits

- environmental pathways and dose estimates.

The source terms task will develop estimates of radioactive emissions from Hanford facilities since 1944. These estimates will be based on historical measurements and production information.

The environmental transport task will reconstruct the movement of radioactive materials from the areas of release to populations. Movement via the atmosphere, surface water (Columbia River), and ground water will be studied.

The environmental monitoring task will assemble, evaluate, and report historical environmental monitoring data. A major effort of this task is to separate Hanford as a source of radionuclide concentrations in the environment from concentrations due to natural sources and nuclear testing fallout.

The demographics, agriculture, and food habits task will develop the data needed to determine the populations that could have been affected by the releases. Population and demographic information will be developed for the general population within the study area. This information will also be developed for several special population groups including the Native American Tribes in the study area, Army personnel stationed at Hanford, Hanford construction workers, and migrant farm workers.

In addition to population and demographic data, the food and water consumption patterns and sources of food and water for these populations must be estimated since these provide a primary pathway for the intake of radionuclides. 
Historical dairy farming practices and milk distribution systems will be studied because milk is a significant pathway for iodine-131 to enter the human body. Cows could have eaten vegetation contaminated with this radionuclide.

The environmental pathways and dose estimates task will use the information produced by the other tasks to estimate the radiation doses populations could have received from Hanford.

Project reports, which have been approved by the Technical Steering Panel, and references used in the reports will be made available to the public in a public reading room. Project progress will be documented in monthly reports, which are available to the public. 
$=$ 


\section{MANAGEMENT SUMMARY}

\section{PROGRESS}

This summary covers progress for the month of July 1989 :

- completed the following scheduled milestone:*

0504-B, Measured River Fish Concentrations

- presented a project status update at the TSP meeting on July 21 in Richland, WA

- presented the potential role of iodine-129 in the HEDR Project at the TSP meeting

- displayed posters at the TSP meeting summarizing available information for the Columbia River between Priest Rapids Dam and McNary Dam

- held a working session on the dose calculational model with PNL staff, TSP members, and three members of the public. The proposed strategy for dose estimation and uncertainty analysis for Phase I was described in detail.

- presented an overview of the HEDR Project's Quality Assurance (QA) program to six members of the TSP. The overview focused on $Q A$ requirements for computer software control, records control, and review and evaluation of reports.

- continued internal PNL clearance on several draft reports, which will become part of the Phase I summary report

- completed entry of meteorological data for 1983 through 1987 into the meteorological data base

- completed verification of the modified MESOILT code

- completed preliminary reviews of the analytical methods used as the basis for determining potential biases and the level of uncertainty for two milestones, 0504-B,Measured River Fish Concentrations and 0503-B, Final River and Sediment Monitoring Data

- completed the creation and verification of data files on radionuclide concentrations in vegetation through August 1946

\footnotetext{
All milestones are internal unless otherwise indicated. All internal milestones contribute to the Phase I summary report.
} 
- met with the Tribal Council of the Confederated Tribes of the Warm Springs Indian Reservation, who voted to proceed with participation in the HEDR Project

- presented update on milk market and food consumption information to the TSP

- continued declassifying early-day, Hanford-originated documents of potential interest/use in the HEDR Project

- provided assistance to a TSP member who was reviewing documents related to the "green run" document, HW-17831 DEL

- continued development of the strategy and detailed procedures necessary to estimate doses and their uncertainties.

\section{MAJOR ISSUES AND ACTION TAKEN}

None.

\section{PLANNED WORK FOR SUBSEQUENT MONTHS}

Work planned for subsequent months includes the following:

- complete the following milestones in August:

0402-B Monthly Average Air Concentrations/Surface Contamination by Location and Radionuclide Computer Files-Units

0403-A Development of Conceptual Model of Radionuclide Transport in the Columbia River/Phase I

0403-B River Water Radionuclide Concentrations at Defined Locations; Sediment Concentrations

0502 l-131 Sample Vegetation Data

0503-B Final River and Sediment Monitoring Data

0602-A Demographic Information for 1944-47 by Age Group, Urbanization Category, and Subpopulation by Year

0603-A Preliminary Food Consumption Parameters 1944-47 for Each Food Type by Age, Sex, Urbanization, Category, Subpopulation

0603-B Preliminary Food Consumption Parameters 1964-66 Kg/Mo Consumed for Each Food Type by Age, Sex, Urbanization Category, Subpopulation

0604-A Preliminary Agricultural Production/Distribution for Non-Milk Products by Grid Cell

0604-B Preliminary Milk Production/Distribution/Consumption for 1944-47 for Each Grid Cell

0604-C Demographic Information for 1964-66 Number and Age/Urbanization/ Subgroup for River Recreation, Drinking River Water 


\section{5-B Preliminary Native American Traditional Diet Description-River}

Pathway

0702-B Soil-to-Plant Model

0704-A Bioassay Data - Tabulate Thyroid Data

0704-B Initiate Investigation of Potential Uses of Bioassay Data

12-B Native American Diet Sensitivity Study-River Pathway

12-G Native American Diet Sensitivity Study-Air Pathway

- provide input to the Phase I summary report, including continuing to prepare and internally clear various preliminary draft reports that will be appended to the Phase I report

- participate in planning for FY 1990

- continue to add input to numerical data base

- complete estimates of the monthly water and sediment concentrations in the Columbia River for use in the Phase I dose calculations

- hold a workshop for tribal technical staff on methods and strategies of data collection

- continue contract negotiations with tribes

- continue to assess the use of historical bioassay data

- continue to declassify reports that address activities from reactor startup to about mid-year 1945

- continue to identify publications that might assist in communicating project concepts to the general public

- continue developing the strategy and procedures for dose estimation and uncertainty analyses for Phase I.

\section{BUDGET STATUS}

Projected expenditures through July 1989

Actual expenditures through July 1989
$\$ 2562 K$

$\$ 2661 \mathrm{~K}$

\section{VARIANCE EXPLANATION}

No significant variance. Two internal milestones were delayed. Milestone 0502, 1-131 Sample Vegetation Data, has been delayed to August 1989 because the amount of time required to extract, enter, and verify vegetation data from original sources has been greater than that originally estimated. Milestone 0504-A, Develop 
Concentration Ratios, has been delayed to Phase II in order to focus efforts on providing data of higher priority for Phase $\mathrm{I}$.

\section{CAPITAL STATUS}

No FY 1989 capital budget. 
PROJECT SUMMARY REPORT

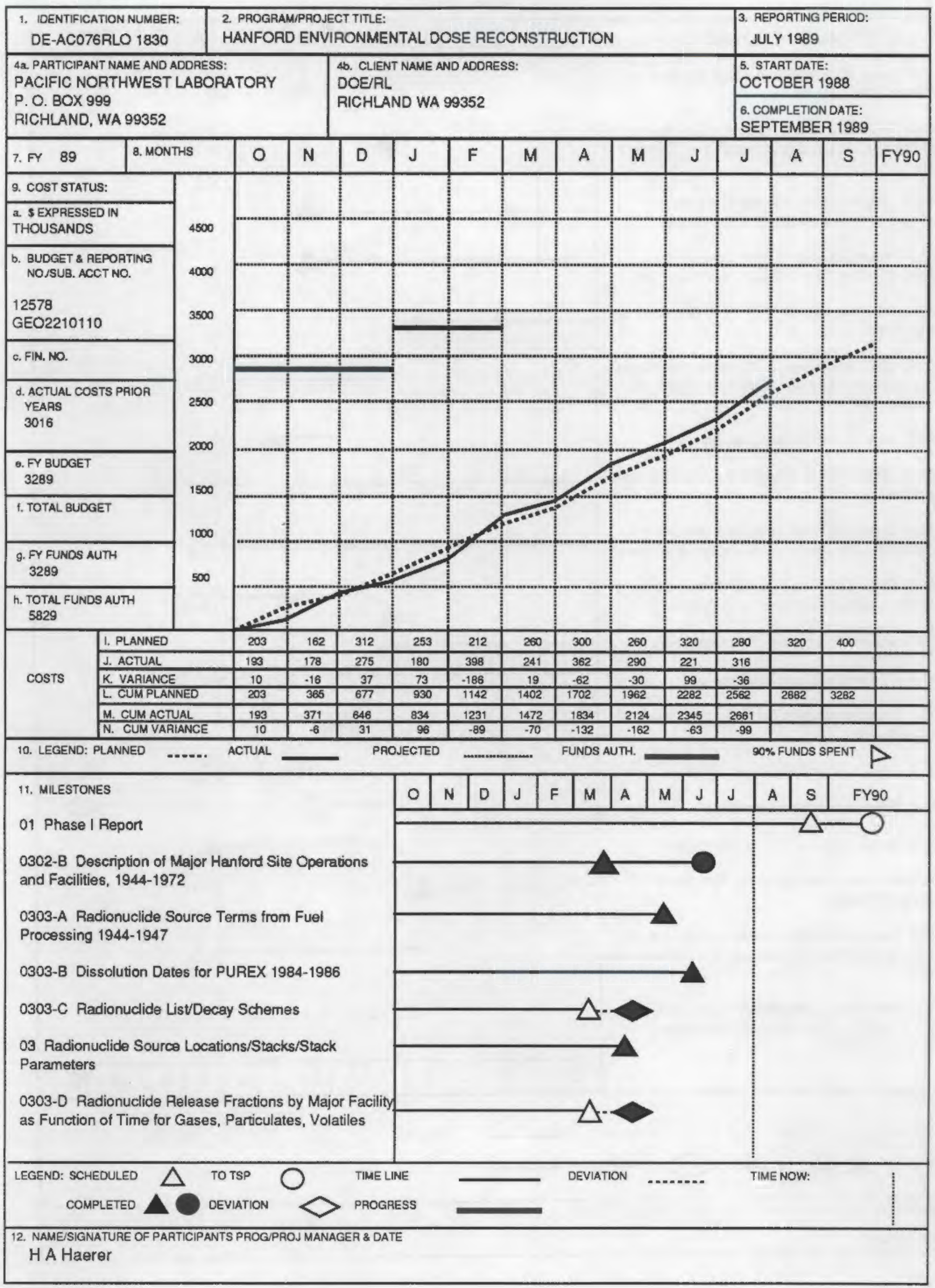


11. MILESTONES, continued

0303-E Focus Radionuclide Release Fractions on Dominant Radionuclides

0303-F Recommendation Regarding Development of Libraries Specific to Hanford Reactors for ORIGEN

Code

0303-G Description of Chemical Form and Atmospheric Chemistry of lodine Emissions

0303-H "Best Estimate" of 1-131 Contained in Irradiated Fuel at Time of Dissolution, 1944-1945

0402-A Preferred MESOI/MESORAD Grid Sizes and Center Points

0402-B Monthly Average Air Concentrations/Surface Contamination by Location and Radionuclide

Computer Files-Units

0402-C Atmospheric Model Development

0402-D Status Report on Meteorological Data Base Development

0403-A Development of Conceptual Model of Radionuclide Transport in the Columbia River/Phase I

0403-B River Water Radionuclide Concentrations at Defined Locations; Sediment Concentrations

0404 Response to Directive 88-4, Ground-Water

0502 I-131 Sample Vegetation Data

0503-A Obtain Preliminary Fiver and Sediment Monitoring Data

0503-B Final River and Sediment Monitoring Data

0504-A Develop Concentration Ratios

0504-B Measured River Fish Concentrations

0505 Preliminary Inventory of Key Monitoring Data/Intemal Draft

0602-A Demographic Information for 1944-1947 by Age Group, Urbanization Category, and Subpopulation by Year

0602-B Preliminary Lifestyle Information for Each Age, Urbanization/Subpopulation Hours/Month

Outdoors vs. Indoors

\section{LEGEND: \\ SCHEDULED \\ COMPLETED

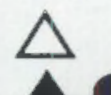 \\ TO TSP \\ 0 \\ TIME LINE \\ 12. NAME/SIGNATURE OF PARTICIPANTS PROG/PROJ MANAGER \& DATE \\ HA Haerer}

$\longrightarrow$ DEVIATION

-..........

TIME NOW 


\section{PROJECT SUMMARY REPORT}

11. MILESTONES, continued

0602-C Census District Boundaries Plotted on Map

0603-A Preliminary Food Consumption Parameters

1944-1947 for Each Food Type by Age, Sex,

Urbanization, Category, Subpopulation

0603-B Preliminary Food Consumption Parameters 1964-1966 Kg/Mo Consumed for Each Food Type by

Age, Sex, Urbanization Catetory, Subpopulation

0604-A Preliminary Agricultural

Production/Distribution for Non-Milk Products by Grid Cell

0604-B Preliminary Milk Production/Distribution/ Consumption for 1944-1947 for Each Grid Cell

0604-C Demographic Information for 1964-1966 Number and Age/Urbanization/Subgroup for River Recreation, Drinking River Water

0604-D Location and Quantity of Irrigation Water Withdrawals

0605-A Preliminary Native American Traditional Diet Description (Air Pathway)

0605-B Preliminary Native American Traditional Diet Description-River Pathway

0702-A Create Fish Model

0702-B Soil-to-Plant Model

0702-C Forage-to-Milk Transfer Model-Mathematical Formulation w/Data/Computer Code "Module"

0702-D Environmental Pathway Model

Selection/Development/Documentation

0703-A Recommendation for Computer System Requirements

0703-B GIS and Data Base System

Recommendation

0704-A Bioassay Data-Tabulate Thyroid Data

0704-B Initiate Investigation of Potential Uses of

Bioassay Data

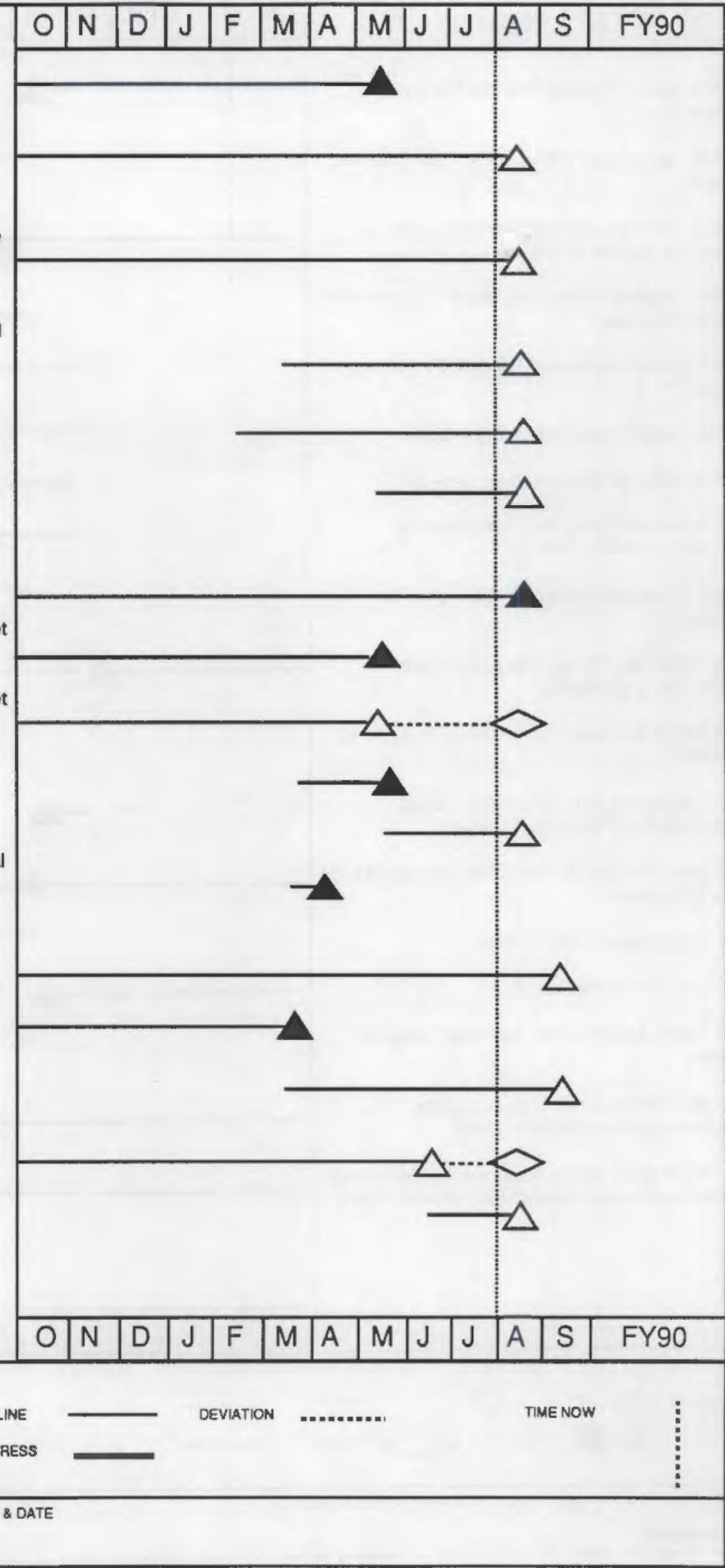




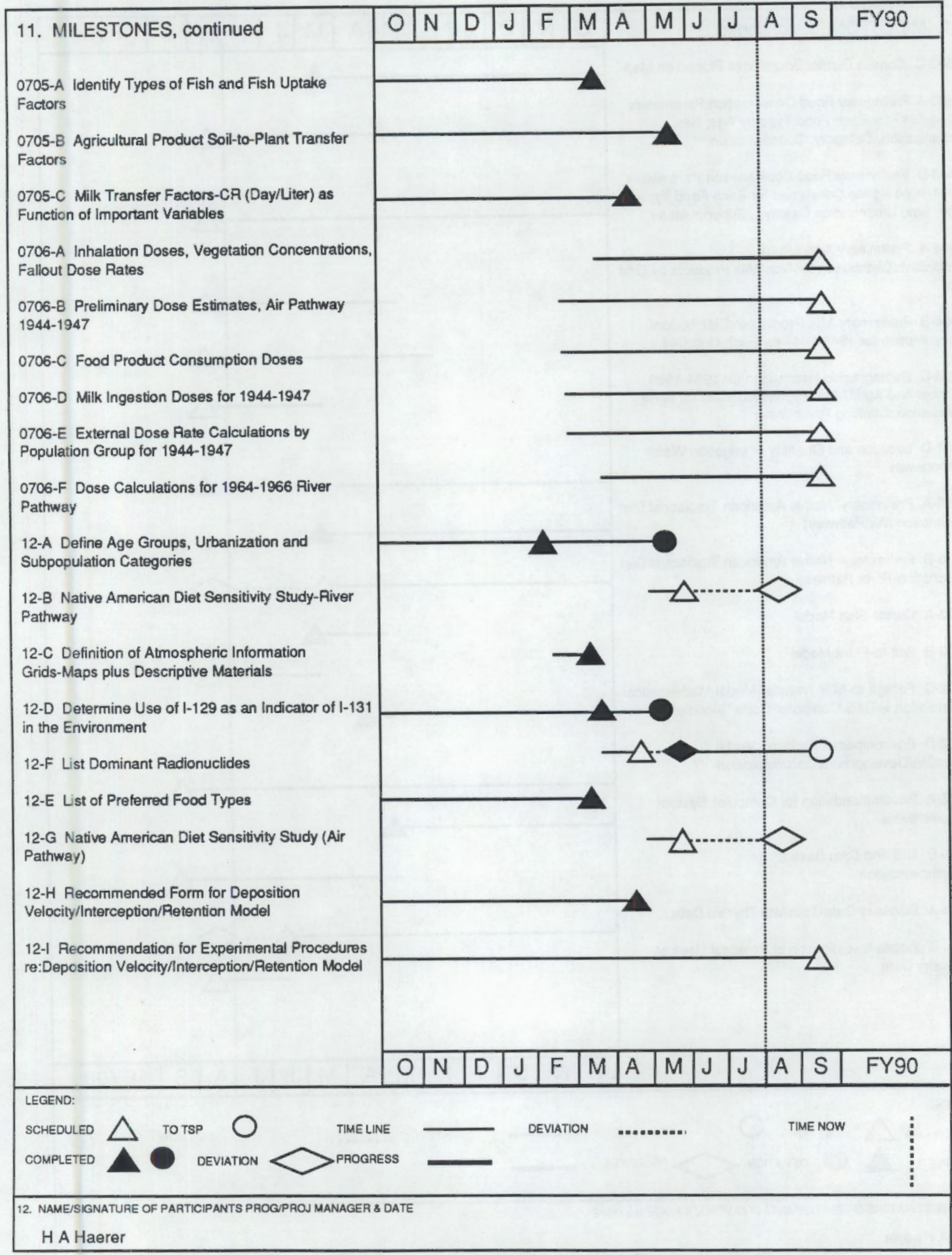




\section{CONTENTS}

PREFACE . . . . . . . . . . . . . . . . . . v

EXECUTIVE SUMMARY . . . . . . . . . . . . . . . . . vii

MANAGEMENT SUMMARY . . . . . . . . . . . . . . . . . xi

SOURCE TERMS

ENVIRONMENTAL TRANSPORT . . . . . . . . . . . . . . . 5

ENVIRONMENTAL MONITORING DATA . . . . . . . . . . . . . 9

DEMOGRAPHICS, AGRICULTURE, FOOD HABITS . . . . . . . . . 11

ENVIRONMENTAL PATHWAYS AND DOSE ESTIMATES . . . . . . 15

INFORMATION RESOURCES . . . . . . . . . . . . . . . . . . . . 17

RECORDS MANAGEMENT . . . . . . . . . . . . . . . . 19

QUALITY ASSURANCE . . . . . . . . . . . . . 21

STATISTICS . . . . . . . . . . . . . . . 23

PROJECT TECHNICAL COORDINATION . . . . . . . . . . . . 25

APPENDIX A - COMMUNICATIONS LOG . . . . . . . . . . . . A.1

\section{FIGURES}

Hanford Environmental Dose Reconstruction Project

Organization Structure. . . . . . . . . . . . . . . . . . . . . vi 


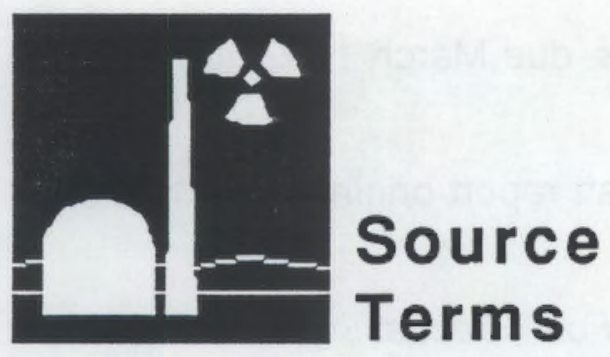

\section{OBJECTIVE}

Source terms are the amount and type of radioactive materials released to the environment. Members of the Source Terms Task will develop estimates of radioactive emissions since 1944 from Hanford facilities based on historical measurements and production information. Source term estimates will be used by Environmental Transport Task members to reconstruct the concentrations of radionuclides in the environment.

Uncertainty in calculated and measured data can result from many factors. Uncertainties in measured emissions may result from early measurement techniques; for calculated emissions, from the differences in the published variables that are used to perform calculations. By comparing the uncertainty in the available data, task staff will determine the most accurate method for developing source terms. For time periods where measured values do not exist, source terms must be calculated from available information. The proposed methods and results of this task will be reviewed, evaluated, and approved by the TSP.

\section{PROGRESS}

Activities for this reporting period included the following:

- held a working session with members of the TSP's Source Term Subcommittee and other TSP members on July 20, 1989. Discussed task activities, their status and completion schedules.

Milestone 0303-F, Recommendation Regarding Development of Libraries Specific to Hanford Reactors for ORIGEN Code, due March 1989 and complete:

- continued internal PNL clearance of the draft report originally completed in March 1989 and revised report to incorporate the informal review comments received from the TSP's Source Terms Subcommittee during the March working session. 
Milestone 0303-C, Radionuclide List/Decay Schemes, due March 1989 and complete:

- continued internal PNL clearance of the draft report originally completed in April 1989.

Milestone 0303-A, Radionuclide Source Terms from Fuel Processing, 1944-1947, due May 1989 and complete:

- continued preparing a final draft report of atmospheric emissions of iodine-131 from fuel processing, 1944-1947. The report will be submitted for internal PNL clearance.

Milestone 0303-G, Description of Chemical Form and Atmospheric Chemistry of lodine Emissions, due May 1989 and complete:

- continued preparing a final draft report describing the chemical form and atmospheric chemistry of iodine emissions at the Hanford Site. The report will be submitted for internal PNL clearance.

Milestone 0303-H, Best Estimate of lodine-131 Contained in Irradiated Fuel at Time of Dissolution, 1944-1945, due May 1989 and complete:

- continued preparing a final draft report of calculated estimates of iodine-131 contained in irradiated fuel at the time of its dissolution, 1944 through 1945. The report will be submitted for internal PNL clearance.

Milestone 0303-B, Dissolution Dates for PUREX 1984-1986, due June 1989 and complete:

- identified the sources of information necessary to determine the fuel dissolution dates at the PUREX Plant from 1984 through 1986. This information will be used to help calibrate the atmospheric transport model. Actual dates will be extracted and incorporated into a preliminary draft report and the Phase I report.

MAJOR PROBLEM AREAS AND ACTION TAKEN

None.

\section{PLANNED WORK FOR SUBSEQUENT MONTHS}

Work planned for subsequent months includes the following: 
- document fuel dissolution dates at the PUREX Plant, 1984-1986, from identified records

- continue to prepare various preliminary draft reports as input to the Phase I summary report and initiate internal PNL clearance of the reports

- continue acquining and documenting information regarding radioactive emissions to the atmosphere from fuel processing, 1944-1947

- continue data input to task numerical data base. 



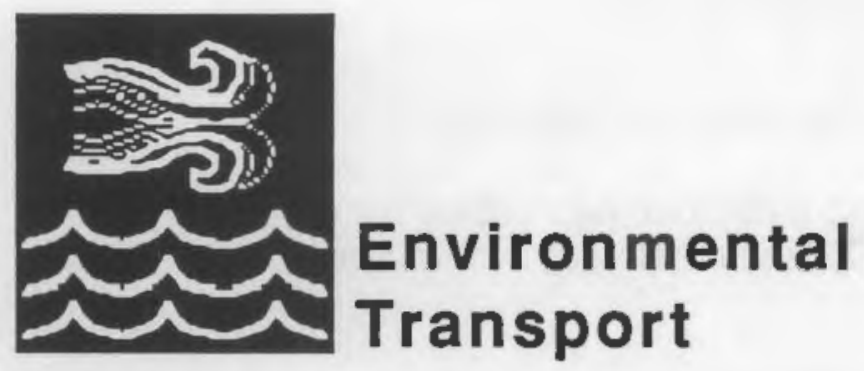

\section{OBJECTIVE}

Members of the Environmental Transport Task will reconstruct the movement of radioactive materials (the source term information) from the areas of release to the accessible environment. Movement via the atmosphere, Columbia River, and ground water will be studied.

To track the releases to the atmosphere from the Hanford Site, meteorological data are needed including wind speed, wind direction, and other data that affect the dispersion of the releases. Mathematical models will be applied to these meteorological data and the source term data to calculate concentrations of radionuclides in the air and on the ground. The TSP will review, evaluate, and provide direction concerning the proposed models.

Reconstruction of the transport of radionuclides in the Columbia River will be based primarily on historical studies of the Columbia River and its tributaries. Computer models will be used to reconstruct radionuclide concentrations in the river for time periods when data were limited or unavailable.

The movement of radionuclides in the ground water will be initially reconstructed by using ground-water monitoring data to estimate the contribution to the surface-water pathway. As in the case of the surface-water pathway, some modeling might be required where data are lacking. 


\section{PROGRESS}

Activities for this reporting period included the following:

- presented posters summarizing available information for the Columbia River between Priest Rapids Dam and McNary Dam at the July TSP meeting.

Milestone 0403-A, Development of Conceptual Model of Radionuclide Transport in the Columbia River/Phase I, due August 1989:

- continued calculations to estimate past radionuclide concentrations in the Columbia River at locations where water was withdrawn for use, but where monitoring data are not available. Concentrations for these locations are estimated using existing monitoring data at other locations to calculate downriver concentrations based on flow rates and volumes, and radionuclide decay and dilution. Members of the Surface-Water Transport Subtask met with the task leader for the Environmental Pathways and Dose Estimates Task to ensure that the approach being used to estimate river concentrations for Phase I was appropriate.

Milestone 0402-C, Atmospheric Model Development, due June 1989 and complete:

- completed verification of the modified MESOILT code. The modified code is identified as MESOILT2, Version 1.0. Computer codes to calculate monthly-average air concentrations, month-end surface contamination, and average deposition rates for census divisions from the MESOILT2 output were prepared.

- continued identifying and representing wind patterns at Hanford. This effort will continue next fiscal year.

Milestone 0402-D, Status Report on Meteorological Data Base Development, due September 1989:

- completed entry of meteorological data for 1983 through 1987 into the meteorological data base. These data are being used in the Phase I calculations.

Milestone 0402-B, Monthly Average Air Concentrations/Surface Contamination by Location and Radionuclide, due August 1989:

- completed computation of the monthly-average air concentrations, month-end surface contamination, and monthly-average deposition rates based on the 1983 through 1987 average meteorological conditions. The results are being transferred to census divisions for the Phase I calculations. 
MAJOR PROBLEM AREAS AND ACTION TAKEN

None.

\section{WORK PLANNED FOR SUBSEQUENT MONTHS}

Work planned for subsequent months includes the following:

- complete estimates of the monthly water and sediment concentrations in the Columbia River for use in the Phase I dose calculations. 


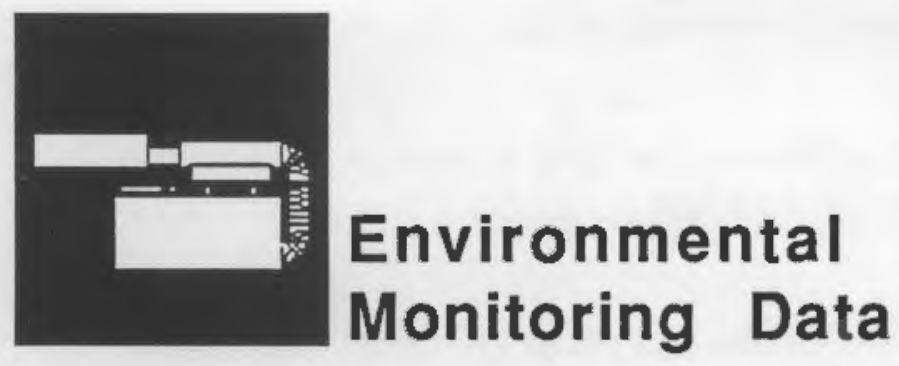

\section{OBJECTIVE}

Members of the Environmental Monitoring Data Task will assemble, evaluate, and summarize key historical measurements of the concentrations of radionuclides in the environment around Hanford. Radionuclide concentrations have been measured at various times in such media as air, drinking water, foods, fish, the Columbia River, soil and in other sample materials. These measurements will be evaluated to estimate their accuracies and then used by Environmental Pathways and Dose Estimates Task staff to estimate radiation doses and by Environmental Transport Task staff to calibrate computer models. Methods to attain this objective will be proposed to the TSP for review, evaluation, and approval.

\section{PROGRESS}

Activities for this reporting period included the following:

Milestone 0502, 1-131 Sample Vegetation Data (1945-46), due August 1989 (deviation from original date):

- completed creating and verifying data files through August 1946 that contain the time, location, measurements of radionuclide concentrations in vegetation, and the documents from which the results were taken. Original counts sheets (radionuclide measurements) were located through August only; only secondary sources were located for the remainder of 1946 .

- began examining the effects of uncertainties in the assumed vegetation sample geometry on sample measurement biases for measurements of iodine-131 activity in vegetation from 1945 through 1947. 
Milestone 0504-B, Measured River Fish Concentrations (64-66), due August 1989 and complete:

- completed a preliminary data compendium and statistical summary by year, season, 8 river sections and 12 fish species for the years 19631966

- completed a preliminary review of the analytical methods used as the basis for determining potential biases and the level of uncertainty in the results.

Milestone 0503-B, Final River and Sediment Monitoring Data (64-66), due August 1989:

- completed preliminary review of the analytical methods as the basis for determining potential biases and the level of uncertainty in the results

- finished entering 1964 through 1966 data into the data base. No routine sediment sampling results were found, though special research studies conducted during this time period provide some data.

Milestone 0504-A, Develop Concentration Ratios (64-66), due FY 1990 (deviation from original data):

- completed collection and summarization of data on radionuclide concentrations in fish flesh. Work to calculate concentration ratios will be delayed to Phase II in order to focus efforts on providing data of higher priority for Phase I.

\section{MAJOR PROBLEM AREAS AND ACTION TAKEN}

None.

\section{PLANNED WORK FOR SUBSEQUENT MONTHS}

Work planned for subsequent months includes the following:

- complete preparation of vegetation data file for 1946

- complete the river water and sediment data file. 


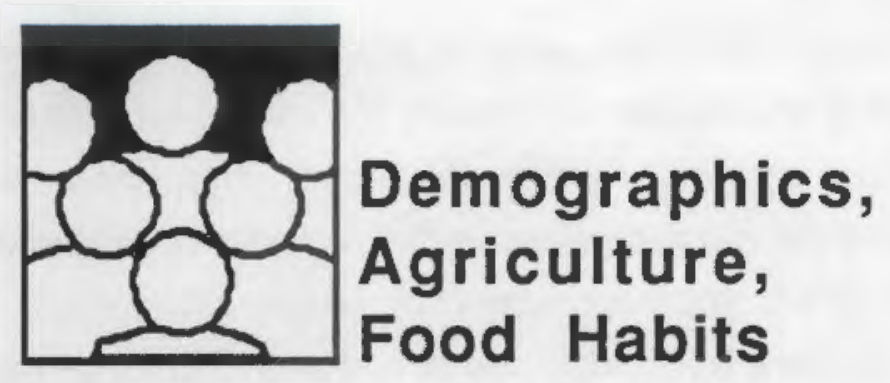

\section{OBJECTIVE}

Task members will develop the demographic, food consumption, and food production information needed to estimate doses.

Demographic information will be developed for the general population and for several special population groups that are not adequately represented by the U.S. Census, including Native American tribes, Army personnel stationed at Hanford, some Hanford construction workers, and migrant workers.

In addition to demographic data, the sources and quantities of food and water consumed must be estimated, because food and water provide pathways for the intake of radionuclides.

Airborne radionuclides from the plant stacks may have been deposited on fruits and vegetables. Consumption of these foods provided a pathway for radionuclide transport to humans. The pathways will be studied. In addition, milk produced from cows represents a significant food pathway for iodine-131 if the cows were fed vegetation contaminated with radionuclides. Dairy farming practices and milk distribution systems will be studied to locate the populations that may have consumed potentially contaminated milk.

Consumption of contaminated fish and shellfish is also a food pathway for exposure to radioactive materials. Estimates of the amount of potentially contaminated fish and shellfish consumed from the Columbia River and ocean bays will be developed through an extensive review of numerous past studies.

Treated Columbia River water was used by some community members downstream from Hanford. Drinking this water provided a pathway for exposure to 
radioactive materials. To estimate the doses from this pathway, it is necessary to know the communities using the water, the amount of water withdrawn, the treatment process, the travel time through the system, and the amount of water consumed. Irrigation water usage downstream from Hanford will also be studied because the radioactive materials in the river water could have been deposited on crops consumed by people or animals. Recreational users of the river could also have been exposed to radiation from the river and shoreline. Food and lifestyle habits of Native Americans that differentiate them from the general population will also be considered. Methods to collect data and to estimate population densities and food consumption have been proposed to the TSP for review, evaluation, and approval.

\section{PROGRESS}

Activities for this reporting period included the following:

Milestone 0605-B, Preliminary Native American Traditional Diet Description (River Pathway), due August 1989:

- met with the Tribal Council of the Confederated Tribes of the Warm Springs Indian Reservation on July 25, 1989. They voted to proceed with the HEDR Project by sending a response to the Request For Proposal.

- reached agreement with an anthropologist to develop baseline dietary estimates for the Native Americans.

Milestones 0602-A and 0604-C, Demographic Information for 1944-1947 by Age Group, Urbanization Category, and Subpopulation by Year and Demographic Information for 1964-1966 Number and Age/Urbanization/Subgroup for River Recreation, Drinking River Water, due August 1989:

- presented demographic update to TSP

- continued to develop county sub-division population estimates

- continued to develop county level, age, sex, and race estimates

- initiated response to outside review of county estimates.

Milestone 0604-B, Milk Production/Distribution/Consumption for 1944-1947 for Each Grid Cell, due August 1989:

- presented milk market information update to TSP 
- met with retired workers of the Carnation Milk Company in Yakima, Washington to discuss milk production/distribution

- developed matrixes for feed intake, milk production, and milk distribution.

Milestones 0603-A and 0603-B, Preliminary Food Consumption Parameters 19441947 for Each Food Type by Age, Sex, Urbanization, Category, Subpopulation, and Preliminary Food Consumption Parameters 1964-1966 Kg/Mo Consumed for Each Food Type by Age, Sex, Urbanization Category, Subpopulation, due August 1989:

- provided food consumption update to TSP.

\section{MAJOR PROBLEM AREAS AND ACTION TAKEN}

None.

\section{PLANNED WORK FOR SUBSEQUENT MONTHS}

Work planned for the subsequent months includes the following:

- scheduled a Native American Workshop for August 8-9, 1989 at the Shilo Inn-Rivershore. The purpose of the workshop is to introduce tribal technical staff to the HEDR Project, present information on potential data sources, and develop preliminary dietary estimates.

- submit final county population estimates report to TSP

- submit draft report on milk production, processing, and distribution to TSP. 


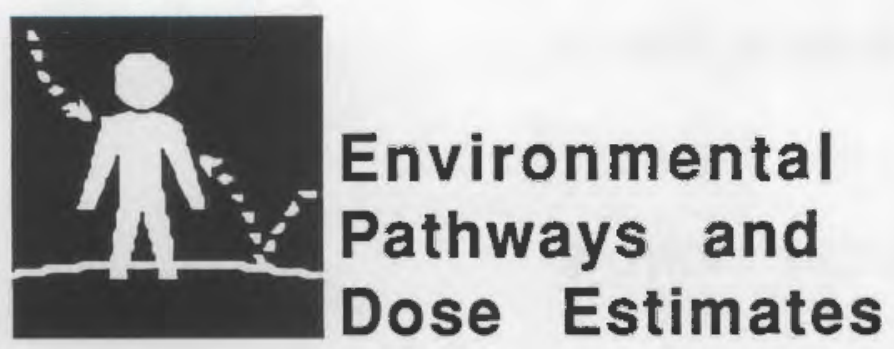

\section{OBJECTIVE}

Task members will use calculated and measured concentrations of radionuclides provided by members of the Environmental Transport Task and the Environmental Monitoring Data Task to calculate doses to populations, typical individuals, and specific individuals. These calculations will include doses via direct transfer of radionuclides from concentrations in air and water to people (via breathing, drinking, immersion, etc.). The calculations will also include doses via radionuclide concentrations in air and water transferred through environmental pathways, such as soil, plants, animals, and fish, to people. All significant decisions on exposure models and input parameters will be presented to the TSP for review, evaluation, and approval.

\section{PROGRESS}

Activities for this reporting period included the following:

Milestone 0703-B, GIS and Data Base Recommendation, due September 1989:

- continued work on the system design requirements (what the code has to do) and the code design specification (how the code has to do it)

- continued to refine the strategy for uncertainty calculations

- developed mechanisms for defining intermediate storage of calculated distributions as histograms

- agreed on a technique for accounting for correlations between various input fractions.

Milestone 0704-A, Bioassay Data - Tabulate Thyroid Data, due August 1989:

- continued entering data and began investigation of various analysis techniques. 


\section{MAJOR PROBLEM AREAS AND ACTION TAKEN}

None.

\section{PLANNED WORK FOR SUBSEQUENT MONTHS}

Work planned for the subsequent months includes the following:

- continue defining the overall structure of the needed HEDR data base and the type of data processing equipment needed for smooth project integration

- complete the code design requirements and code design specification documents. 


\section{Information Resources}

\section{OBJECTIVE}

Members of the Information Resources Task will work with the other task members to meet information needs, including ensuring that all data referenced in the reports are publicly available and establishing a microcomputer-based tracking system for ready retrieval of historical information.

\section{PROGRESS}

Activities for this reporting period included the following:

- declassified two early-day, Hanford-originated documents of potential interest/use in the HEDR Project and provided them to appropriate task leaders and the public domain

- provided the DOE-RL Public Reading Room with 44 Hanford-Site originated documents of potential interest/use in the HEDR Project. Approximately 70 remain to be sent.

- identified lists of additional serial/periodic documents that may include raw data of interest regarding the "green run." Most of these documents had been destroyed by DOE many years ago as part of routine, periodic purges of records of a certain age that are no longer considered necessary to maintain.

- provided assistance to a TSP member who was reviewing "green run" related documents during a week-long visit

- continued to search for documents that address silver reactor capabilities, performance, and incidents

- continued to search for documents containing pertinent information of stack filter samples and scrubber samples during 1946 through 1949

- added new citations to the tracking system. 


\section{MAJOR PROBLEM AREAS AND ACTION TAKEN}

None.

\section{PLANNED WORK FOR SUBSEQUENT MONTHS}

Planned work for subsequent months includes the following:

- identify articles that might assist in communicating technical subject matter (e.g., risk, uncertainty, sensitivity) to public audiences

- continue to add input to the information resources tracking data base

- continue to provide documents to the DOE-RL Public Reading Room in an orderly, timely fashion

- develop a list of Hanford-originated raw data logs/notes of potential interest/use to the HEDR Project

- declassify, with or without deletions, duPont operating history volumes that address activities from startup to about mid-year 1946

- identify and collect significant documents that address silver reactor capabilities, performance, and incidents, especially at the Redox Plant

- continue to identify and collect documents and/or data of potential interest/use to the HEDR Project that address activities during the years from reactor startup through 1949

- identify documents that present information on stack filter samples and scrubber samples for 1946 through 1949

- watch for information that may explain in detail, and support data in, "green run" document HW-17381 DEL. 


\section{Records \\ Management}

\section{OBJECTIVE}

Members of the Records Management Task provide storage and control of completed project records, maintain an automated inventory of all project documentation, and provide a reference service to project staff and the TSP.

\section{PROGRESS}

Activities for this reporting period included the following:

- received and processed project records.

MAJOR PROBLEM AREAS AND ACTION TAKEN

None.

\section{PLANNED WORK FOR SUBSEQUENT MONTHS}

Work planned for subsequent months includes the following:

- continue processing incoming project records

- continue transferring processed project records to the DOE-RL Public Reading Room. 


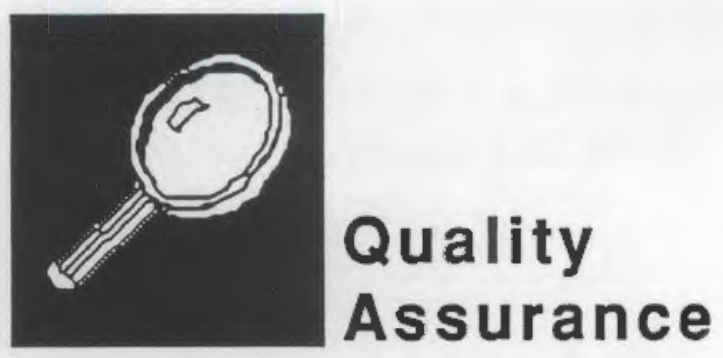

\section{OBJECTIVE}

The objective of this task is to ensure continuous quality assurance (QA) support and coordination with all project tasks. This objective is met through the identification and documentation of QA requirements in the form of a QA Plan and periodic monitoring of project activities during the life of the project to ensure compliance with these requirements.

\section{PROGRESS}

Activities for this reporting period included the following:

- presented an overview of the HEDR Project's QA program to six members of the TSP. This overview focused on QA requirements for computer software control, records control, and review and evaluation of reports.

- initiated training assignments to HEDR staff in the Source Terms Task

- continued contacting task leaders to determine which upcoming task activities may require formal surveillance to ensure compliance with $\mathrm{OA}$ requirements.

\section{MAJOR PROBLEM AREAS AND ACTIONS TAKEN}

None.

\section{PLANNED WORK FOR SUBSEQUENT MONTHS}

Work planned for subsequent months includes the following:

- assist in implementing QA program requirements for HEDR staff training and software control requirement identification 
- perform surveillance of software control requirements and records control

- issue remaining HEDR procedures: HEDR-TP-3, HEDR Documentation of Critical Decisions and HEDR-TP-4, HEDR Data Quality Objectives. 


\section{statsicics}

\section{OBJECTIVE}

Task members will provide statistical support to members of technical tasks and will develop and apply sensitivity and uncertainty analyses. Sensitivity analyses will be used to identify parameters with the greatest influence on dose estimates. Using sensitivity analyses results, project staff can focus resources where the benefit in terms of accurate dose estimates is greatest. Uncertainty analyses enable task leaders to determine the extent to which the accuracy and precision of the dose estimates are influenced by accuracy and precision in the input parameters.

\section{PROGRESS}

Activities this reporting period included the following:

- gave a presentation at the TSP/PNL working session on the project computational structure held on July 19,1989 , where the proposed strategy for dose estimation and uncertainty analysis for Phase I was described in detail

- continued working with other HEDR task staff to develop the strategy and detailed procedures needed to estimate doses and their uncertainties in Phase I, including

- specifying the proposed method for statistically estimating monthly average radionuclide concentrations in fish for 1964 through 1966, using fish measurements collected during that time period

- specifying the proposed method for statistically estimating average time-integrated monthly air concentrations, deposition rates, and surface contamination levels using results from the air dispersion model developed by the Environmental Transport Task 
- resolving issues that were raised at the July 19,1989 working session concerning details of the Phase I uncertainty analysis.

\section{MAJOR PROBLEM AREAS AND ACTION TAKEN}

None.

\section{PLANNED WORK FOR SUBSEQUENT MONTHS}

Work planned for subsequent months includes the following:

- assist in the development of strategies and detailed procedures for dose estimation and uncertainty analyses for Phase I

- assist the Demographics, Agriculture, Food Habits Task in completing TSP Directive 89-7, "Presentation of Technical Material to the Public"

- conduct analyses to approximate the uncertainty in correction factors being developed to obtain corrected iodine-131 measurements in vegetation for 1945 through 1947

- conduct Phase I sensitivity/uncertainty analyses

- plan an early 1990 workshop to review the uncertainty analyses conducted in Phase I and to plan for expanding and refining those analyses in Phase II. 


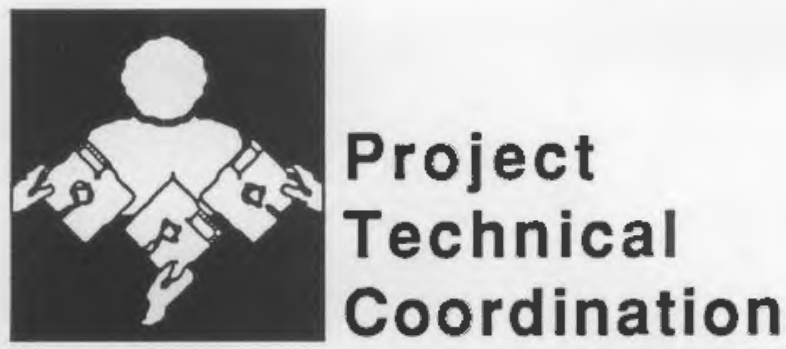

\section{OBJECTIVE}

The objective of the Project Technical Coordination Task is to provide a general technical overview of the project to ensure that appropriate information is generated from the technical tasks for performing the final dose calculations.

\section{PROGRESS}

Activities this reporting period included the following:

- prepared for and participated in the TSP/PNL working session on the overall project data flow and computational structure. Outlined the project QA requirements for calculations to the TSP.

- selected the locations where surface water calculations would be required to fit into the computational scheme for Phase I using input from the Environmental Transport and Environmental Monitoring Tasks

Milestone 12-F, List Dominant Radionuclides, due May 1989 and complete:

- continued preparing documentation using additional input from the TSP that was received following the July meetings.

\section{MAJOR PROBLEM AREAS AND ACTION TAKEN}

None.

\section{PLANNED WORK FOR SUBSEQUENT MONTHS}

Work planned for the subsequent months includes the following:

- continue defining the overall structure of the needed HEDR data base and the type of data needed for smooth project integration. 



\section{APPENDIX A}

\section{Communications Leg}


COMMUNICATIONS LOG - JULY 1989

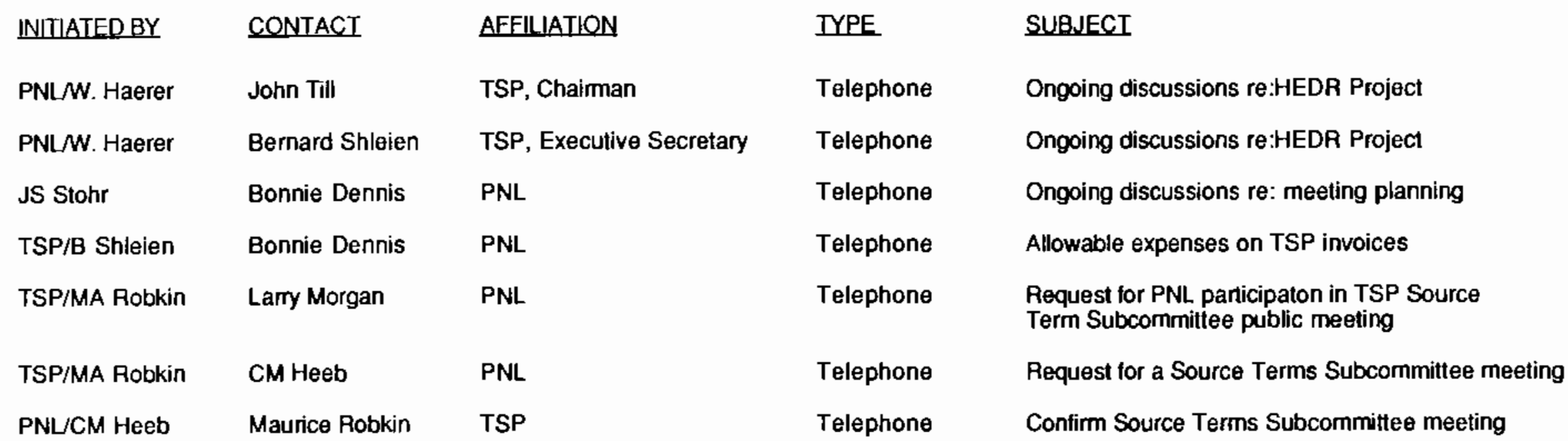




\section{DISTRIBUTION}

No. of

Coples

\section{OFFSITE}

D. S. Barth

University of Nevada

4505 Maryland Parkway

Las Vegas, NV 89154

W. A. Bishop

2503 Wedgewood Court SE

Olympia, WA 98501

M. L. Blazek

Oregon Department of Energy

625 Marion Street N.E.

Salem, OR 97303

G. G. Caldwell

Deputy Director

Arizona Dept of Health Services

1740 W. Adams St.

Phoenix, AZ 95007

S. N. Davis

Dept of Hydrology \&

Water Resources Bldg 11

University of Arizona

Tucson, AZ 85721

N. J. Germond

224 Iron Mountain Blvd.

Lake Oswego, OR 97034

P. C. Klingeman

College of Engineering

Merryfield Hall 100

Oregon State University

Corvallis, OR 97331-2410

K. J. Kopecky

Fred Hutchinson Cancer

Research Center

1124 Columbia Street

Seattle, WA 98104
No. of

Coples
R. L. Morrill

Dept of Geography

DP-10

University of Washington

Seattle, WA 98195

A. H. Murphy

Depts of Atmospheric Sciences and Statistics

Strand Agricultural Hall Rm 331

Oregon State University

Corvallis, OR 97331

V. Nguyen

EWA, Inc.

133 1st Ave. N.

Minneapolis, MN 55401

D. W. Price

Agricultural Economics

Hulbert Hall Room 211

Washington State University

Pullman, WA 99163

\section{A. Robkin}

Radiological Sciences SB-75

University of Washington

Seattle, WA 98195

G. S. Roessler

$\%$ Ervin Roessler

$410 \mathrm{E}$. Main

Elysian, MN 56028

B. Shleien

2421 Homestead Drive

Silver Springs, MD 20902

A. P. Slickpoo Sr.

P. O. Box 331

809 Nez Perce Lane

Kamiah, ID 83536 
No. of

Coples

J. E. Till

Rt. 2 Box 122

Neeses, South Carolina 29107

J. V. Flett

Spokane Business Council

P. O. Box 100

Wellpinit, WA 99040

Z. Jackson, Chairman

Tribal Council

Confederated Tribes of the

Warm Springs Reservation

P. O. Box C

Warm Springs, OR 97761

G. Nenema, Chairman

Kalispel Business Council

P. O. Box 39

Usk, WA 99180

E. H. Patawa, Chairman

Board of Trustees

Confederated Tribes of the

Umatilla Indian Reservation

P. O. Box 638

Pendleton, OR 97801

3 DOE Office of Scientific and Technical Information

Technical Information Center

P. O. Box 62

Oak Ridge, TN 37830

10 J. S. Stohr

Office of Nuclear Waste Mgmt

Department of Ecology

Mail Stop PV-11

Olympia, WA 98504

J. Ruttenber

Centers for Disease Control

2858 Woodcock Blvd

Koger Center F-28

Atlanta, GA 30341
No. of

copies

\author{
D. E. Walker Jr. \\ P. O. Box 4147 \\ Boulder, CO 80306
}
A. V. Pinkham, Chairman
Nez Perce Tribal Exec Committee
P. O. Box 305
Lapwai, ID 83540

M. Sampson, Chairman

Tribal Council

Confederated Tribes and Bands of the Yakima Indian Nation

P. O. Box 151

Toppenish, WA 98948

E. Stensgar, Chairman

Coeur d'Alene Tribal Council

Plummer, ID 83851

M. Tonasket, Chairman

Colville Business Council

P. O. Box 150

Nespelem, WA 99165

R. R. Mooney

Washington State Dept of

Social \& Health Services

LE-13

Olympia, WA 98504-0095

D. Oliver, R.S., M.P.A.

Hazardous Waste Coordinator

Toxic Substances Section

Dept of Social \& Health Services

LD-11

Olympia, WA 98504

S. Simon

Dept of Environmental Science, CB7400

University of North Carolina

Chapel Hill, NC 27599 
No. of

Coples

A. P. Hull

Safety \& Environmental

Protection Division

Bldg 535A

Brookhaven National Laboratory

Upton, NY 11973

T. D'Arcy McGee

Counsellor (Energy)

Canadian Embassy

1746 Massachusetts Ave NW

Washington, DC 20036

J. D. Mulder

Public Health Liaison to EPA

U.S. EPA

1200 Sixth Ave.

Seattle, WA 98101

L. Dufty, S-1

Department of Energy

Forrestal Bldg Room 7B-118

1000 Independence Ave.

Washington, DC 20585

R. Geiger, EH-231

Department of Energy

Forrestal Bldg Room 3G-089

1000 Independence Ave.

Washington, DC 20585

C. Moris, DP-3

Department of Energy

Forrestal Bldg Room 4A-045

1000 Independence Ave.

Washington, DC 20585

C. Bastin, NE-471

Department of Energy

Room F-416

Germantown, MD 20545
No. of

Coples

F. R. Dixon

Chief of Bureau of Preventive

MedicineDept of Health \& Welfare

State House

Boise, ID 83720

W. J. Roberds

Golder Associates

4104 148th N.E.

Redmond, WA 98052

E. Magione, Director

Division of Disease Control

\& Environmental Epidemiology

Colorado Dept of Health

4210 E. 11th Ave.

Denver, CO 80220

S. Convis, MA-295

Department of Energy

Forrestal Bldg Room 7E-054

1000 Independence Ave.

Washington, DC 20585

A. Fingeret, GC-22

Department of Energy

Forrestal Bldg Room 6H-087

1000 Independence Ave.

Washington, DC 20585

M. Leifer, EH-232

Department of Energy

Forrestal Bldg Room 3G-089

1000 Independence Ave.

Washington, DC 20585

J. Tseng, EH-20

Department of Energy

Forrestal Bldg Room 4A-045

1000 Independence Ave.

Washington, DC 20585 
No. of

Coples

D. Nelson, EH-33

Department of Energy

Room G-144

Germantown, MD 20545

V. Trice, DP-122

Department of Energy

Room A-222

Germantown, MD 20545

L. Waldo, DP-122

Department of Energy

Room A-222

Germantown, MD 20545

\section{ONSUTE}

1 Hanford Environmental Health Eoundation

S. E. Dietert

$\mathrm{H} 1-03$

2 Westinghouse Hanford Company

G. D. Carpenter

H4-15

D. E. Wood

$\mathrm{H} 4-51$

15 DQE Richland Operations

J. H. Anttonen, AMR

R. F. Brich, SED

A. Holten, SED

J.R. Hunter, OPD

J. J. Keating, AMS

M. J. Lawrence, MGR

E. E. Pride, OCC

A. J. Rizzo, AMO

R. M. Rosselli, AMA

R. R. Tibbatts, FRD

M. W. Tiernan, SED

K. J. Wheeless, COM

M. J. Zamorski, OPD
A5-10

(2) $\mathrm{A} 5-55$

A5-55

A6-55

A6-54

A7-50

A4-52

A6-53

A7-70

A7 -88

(2) $\quad A 5-55$

A7-75

A6-55
No. of

coples

B. Goldsmith, ER-73

Department of Energy

Room E-222

Germantown, MD 20545

G. Sherwood, NE-12

Department of Energy

Room E-478

Germantown, MD 20545

R. Mathias, ER-70

Department of Energy

Room F-208

Germantown, MD 20545

47 Pacific Northwest Laboratory

D. L. Alamia

K3-70

G. L. Andrews

P7-80

W. F. Bair

K4-14

J.W. Brothers

$\mathrm{K} 1-86$

D. S. Broussard

$\mathrm{K} 1-67$

D. B. Cearlock

$\mathrm{K} 1-42$

T. D. Chikalla

$\mathrm{K} 1-74$

T. T. Claudson

$\mathrm{K} 1-45$

$R$ Cuello

P7-50

G. H. Cunningham K1-59

J.M. Davidson K1-66

J.W. Falco

$\mathrm{K} 6-78$

M. D. Freshley

$\mathrm{K} 6-96$

R. O. Gilbert

$\mathrm{K} 1-85$

S. P. Gydesen

P8-55

H. A. Haerer

$\mathrm{K} 6-89$

M. S. Hanson

$\mathrm{K} 1-51$

J. Johnson

W. E. Kennedy

R. C. Liikala

A. H. McMakin

K3-54

$\mathrm{K} 1-57$

$\mathrm{K} 6-86$

L G. Morgan

K2-35

B. A. Napier

K3-54

T. A. Nelson

K1-55

R. E. Rhoads

K6-64

J. T. A.Roberts

$\mathrm{K} \uparrow-40$ 
No. of

Copies

Racific Northwest Laboratory, contd.

R. L. Skaggs

R. G. Stevens

J. A. Stottlemyre

W. L. Templeton

W. R. Wiley

R. K. Woodruff

H.E. Wyer

Project Office Files

Records Center

Technical Library

Public Reading Room
$\mathrm{K} 6-77$

$\mathrm{K} 6-45$

K6-94

$\mathrm{K} 1-30$

$\mathrm{K} 1-46$

(2) $\mathrm{K} 5-09$

$\mathrm{K} 1-11$

(5) $\mathrm{K} 6-89$

K3-70

(2)

(5) A1-65 


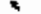

